\title{
THE PROPERTY (RELATIONSHIPS) AMENDMENT ACT 2001: A CONCEPTUAL CHANGE
}

\author{
Nicola Peart*
}

When the Matrimonial Property Act 1976 was introduced, Tony Angelo and Bill Atkin analysed the Act in conceptual terms and welcomed the change from a purely separate property regime to a community property system. It steered an acceptable middle course between competing demands. The Act operated as a deferred community property regime on separation, which was relatively simple and predictable for most couples. This paper analyses the changes made by the Property (Relationships) Amendment Act 2001 and concludes that it has changed the conceptual basis of the property sharing regime, but not in a coherent or principled manner. While the community property system is strenghened in some respects, it is weakened in other respects and overall it introduces an undesirable level of uncertainty and unpredictability.

\section{INTRODUCTION}

This Festschrift in honour of Professor Tony Angelo is a fitting tribute to a man of outstanding international repute. He has had a long and distinguished career in academia, much of it devoted to comparative law and conflict of laws. His interest in foreign jurisdictions is reflected in much of his writing and has enabled him to place New Zealand developments in a broader, international context. An article he wrote thirty years ago with Bill Atkin on New Zealand's newly adopted Matrimonial Property Act 1976 is one of many such contributions and forms the basis of this paper. ${ }^{1}$

In that article Angelo and Atkin analysed the new Act in conceptual terms, comparing New Zealand's matrimonial property regime to systems in other common law and civil law jurisdictions in an attempt to categorise it in an international context. They concluded that the Act did not fit any of the conventional matrimonial property regimes. It was not a separate property regime, as the

* Professor of Law, University of Otago. I am indebted to Sarah McLean, BA(Hons) LLB(Hons) for her research assistance in the preparation of this paper. Thank you also to my colleagues Professor Mark Henaghan and Margaret Briggs for helpful discussions on the ideas expressed in this paper.

1 A H Angelo and W R Atkin "A Conceptual and Structural Overview of the Matrimonial Property Act 1976" (1977) 7 NZULR 237. 
Matrimonial Property Act 1963 was, because the Act established an equal sharing regime on dissolution of the marriage. Nor was it a true community property regime, such as those in civil law countries, because equal sharing was only a presumption, albeit a strong presumption in respect of domestic assets. $^{2}$ The concept of community property nonetheless featured prominently. The regime was akin to a "community of surplus" system where there is no community while the marriage is on foot, but on dissolution the gains made during the marriage are equally shared. ${ }^{3}$ The Matrimonial Property Act 1976 differed from that system by including certain pre-marital assets, namely the family home, the family chattels, and assets acquired in contemplation of marriage for the common benefit and common use of the spouses. ${ }^{4}$ The community of assets was therefore potentially larger than in a community consisting only of surpluses. Nor was the community entirely deferred until dissolution of the marriage. The protected interest in the matrimonial home gave spouses a property interest during the marriage. ${ }^{5}$ That was more in line with a "community of property" system than a community of surplus. ${ }^{6}$ The Act thus drew heavily on community property concepts. However, because of the judicial discretion to depart from equal division, the system could best be described as one of deferred participation in a community of assets rather than one of deferred community property.

The change to some form of community followed logically from revisioning marriage as a partnership between two equal persons. ${ }^{7}$ The Act had shifted the focus from the spouses' property to their relationship. Both spouses were presumed to contribute equally to the marriage relationship, albeit in different ways. Contributions were broadly defined to include monetary as well as nonmonetary contributions, and the Act stipulated that a contribution of a monetary nature was not to be presumed to be of greater value than a contribution of a non-monetary value. ${ }^{8}$ The equality of those

2 Matrimonial Property Act 1976, ss 11-15.

3 Angelo and Atkin defined "community of surplus" as a system in which the spouses share the property gains made by the spouses during the marriage: above $n 1,240$. This is a system of separate property because the community does not come into existence until the end of the marriage. It is the default system in Germany (§1365-1369 BGB).

4 Matrimonial Property Act 1976, s 8.

5 Matrimonial Property Act 1976, s 20.

6 In a "community of property" system the spouses share some or all of their property during the marriage and upon dissolution. That is the default system in South Africa (Matrimonial Property Act 1984, ss 2 and 1417) and the Netherlands (Burgerlijk Wetboek, Book 1, arts 93-96) where all assets brought into and acquired during the marriage are included in the community. In France only the after-acquired property is part of the community and that system operates as the default system: Code Civil, arts 1400-1491.

7 Angelo and Atkin, above n 1, 245-247.

8 Matrimonial Property Act 1976, s 18(2). 
contributions justified an equal division of the partnership assets, subject to limited exceptions. ${ }^{9}$ If one of those exceptions applied, the relationship property was divided according to the parties' contributions to the partnership, not their contributions to the property. The notion of the marriage being a partnership of equals thus featured strongly in the Act.

As in community property systems in civil law countries, ${ }^{10}$ the spouses could choose to contract out of the statutory regime. ${ }^{11}$ That required a formal agreement preceded by independent legal advice about the effects and implications of the agreement. ${ }^{12}$ Avoiding the statutory regime thus required a conscious decision and compliance with requirements intended to ensure that the choice was voluntary and fully informed.

In the course of their analysis of the Act, Angelo and Atkin identified several other features about the Act. One was that the Act was designed for married couples, not for people who had agreed to live together. ${ }^{13}$ As such, the Act represented a return to a more traditional concept of marriage, where marriage is seen as something more than a contract, it confers a status. ${ }^{14}$ It was by virtue of their married state that couples came within the ambit of the Act.

Another feature was that the Act was presented as a code, a self-sufficient entity. Section 4 displaced the rules and presumptions of the common law and equity, and provided that all other statutes were to be read subject to the Matrimonial Property Act unless there was an express provision to the contrary. Yet, other Acts relating to matrimonial property, such as the Family Protection Act 1955 and Joint Family Homes Act 1964, were not incorporated and continued to apply. Nor did the Act apply to marriages ending on death. It only applied to marriages ending on separation. ${ }^{15}$ The old Matrimonial Property Act 1963 continued in force for matrimonial property claims after death. ${ }^{16}$ As property adjustment under that Act was at the Court's discretion and based

9 The presumption of equal division of domestic assets could be rebutted only if the duration of the marriage was less than 3 years (s 13) or if there were extraordinary circumstances that made equal sharing repugnant to justice (s 14). Equal division of other matrimonial property could be avoided more easily by showing that one spouse had made a clearly greater contribution than the other spouse (s 15).

10 Code Civil (France) art 1387; BGB (Germany) §1410; Burgerlijk Wetboek, arts 114 and 121, Book 1 (Netherlands); Matrimonial Property Act 1984, s 2 (South Africa).

11 Matrimonial Property Act 1976, s 21.

12 Idem.

13 Although cl 49 of the Matrimonial Property Bill 1975 did initially include de facto couples, strong opposition led to their removal before the Bill was passed into law.

14 Hyde v Hyde (1866) LR 1 P\&D 130, referred to by Angelo and Atkin, above n 1, 248.

15 Matrimonial Property Act 1976, s 5.

16 Matrimonial Property Act 1976, s 57(4). 
upon contributions to property, ${ }^{17}$ rather than contributions to the marriage relationship, equal division was not presumed and seldom achieved. ${ }^{18}$ That often put widows especially in a worse position than separated wives. The Government appreciated this anomaly and promised an early review of the Act to extend it to marriages ending on death, but that promise was not kept.

Overall, Angelo and Atkin appeared to welcome the adoption of some form of community of property in marriage. They thought the Act was an attempt to steer an acceptable middle course between the competing demands of marriage as a partnership, which required some form of community of property, and the pathological condition of marriage with its high divorce rate where separation of property was preferred. ${ }^{19}$ They expressed the hope that the Act would succeed.

\section{THE MATRIMONIAL PROPERTY ACT IN ACTION}

The Matrimonial Property Act 1976 represented a radical change from the discretionary system of the past. Not surprisingly, it attracted a lot of comment at the time of its introduction, much of it critical. ${ }^{20}$ But since then the Act has received remarkably little comment. ${ }^{21}$ After the Court of Appeal resolved some key issues in a series of decisions in 1979, the Act's basic principles were mostly settled, widely understood and generally accepted. ${ }^{22}$ The presumption of equal sharing was

17 Matrimonial Property Act 1963, ss 5 and 6.

18 For example Re Baigent (decd) (1988) 4 FRNZ 170 (HC) where the widow was awarded 20 per cent of the home and all other assets. In Triggs $v$ Bramley [1992] NZFLR 774 (HC) the matrimonial home was a premarital asset in which the widow was awarded a 25 per cent interest as recognition of her contribution to its maintenance. Mora v Mora [1988] 1 NZLR 214 (CA) marked a turning point. After a long marriage in which the widow worked very hard on her husband's farm, she was awarded 40 pre cent of the farm. She would have been awarded an equal share had it not been for the fact that the husband bought the farm from his family and the price included an element of gift. Awards became more generous then, and sometimes the property was divided equally, as in Re Balchin (4 November 1994) CA 204/94.

19 Angelo and Atkin, above n 1, 258.

20 R L Fisher "The Matrimonial Property Bill - Misguided chivalry?" [1976] NZLJ 253; B D Inglis QC "The Matrimonial Property Bill - Comparable chaos" [1976] NZLJ 321; A H Angelo and W R Atkin "The Matrimonial Property Bill: some further thoughts" [1976] NZLJ 424; Margaret Nixon "The Matrimonial Property Bill - Misguided chivalry?" [1976] NZLJ 438; W R Atkin "The New Regime of Family Property" [1977] NZLJ 81; H Sargisson "Matrimonial Property Legislation - its History and a Critique of the present New Zealand Law" (1976-1979) 3 AULR 82; and E N Scott "Forgetting the Debates of Lawyers: the Codification of Family Law in New Zealand" (1975-1977) 8 VUWLR 436.

21 Papers presented at a symposium on "Family Property, Law and Policy" in 1994 are among the few to comment critically on the Act's operation in practice: Bill Atkin, Graeme Austin and Virginia Grainer (eds) Family Property, Law and Policy (New Zealand Institute of Advanced Legal Studies and Victoria University of Wellington Law Review, Wellington, 1995).

22 Martin v Martin [1979] 1 NZLR 97 (CA), Dalton $v$ Dalton [1979] 1 NZLR 113 (CA) and Williams v Williams [1979] 1 NZLR 122 (CA) dealt with the narrow exceptions to equal division of the matrimonial home in ss 13 and 14, while Barton $v$ Barton [1979] 1 NZLR 130 (CA) and Reid v Reid [1979] 1 NZLR 572 (CA) dealt with the division of the balance of matrimonial property. 
not easy to rebut, not even in relation to non-domestic matrimonial property, unless there were business assets or a farm. ${ }^{23}$ For most couples equal sharing was the norm. ${ }^{24}$ In practice, therefore, the Act operated as a system of deferred community property.

The statutory sharing regime was an "opt out" system. Parties were free to contract out of the Act. ${ }^{25}$ However, it soon became apparent that there was no guarantee the agreement would be upheld on separation. Even if the parties had been fully informed about the effects and implications of the agreement, it could still be set aside if the agreement was found to be unjust or to have become unjust over time. ${ }^{26}$ That occurred quite commonly, in which case the equal sharing regime applied with full force. ${ }^{27}$

A more effective way of avoiding the regime was not to own property. The Act applied only to assets beneficially owned by either of the spouses at the time of separation. ${ }^{28}$ Assets held in discretionary trusts or owned by companies did not generally come within the ambit of the Act. ${ }^{29}$ The Act provided some redress for dispositions intended to defeat a spouse's rights under the Act, but proving the required intent was notoriously difficult and rarely successful. ${ }^{30}$ Trusts and companies thus provided a reliable form of protection against claims under the Act. ${ }^{31}$

The Matrimonial Property Act continued in force with little substantive amendment for 25 years. A Government Working Group, established in 1988 to update the Act and provide for the

23 Report of the Working Group on Matrimonial Property and Family Protection (Government Printer, Wellington, 1988) 7.

24 Working Group Report, ibid, 4.

25 Matrimonial Property Act 1976, s 21.

26 The agreement was void if the prescribed requirements had not been met: Matrimonial Property Act 1976, s 21(8)(a). Even if the agreement complied with the prescribed requirements, it could later be set aside if it would be unjust to give effect to it: Matrimonial Property Act 1976, s 21(8)(b).

27 Wood $v$ Wood [1998] 3 NZLR 234 (HC).

28 See the definitions of "owner" and "property" in Matrimonial Property Act 1976, s 2(1).

29 An interest in a discretionary trust was held not be property for purposes of the statutory definition of "property" in Nation v Nation [2005] 3 NZLR 46 (CA). In $S$ v S [2008] NZFLR 711 (Family Court) a wife was unable to get an occupation order in respect of the home, because the home was owned by a company. Although both of these cases were decided under the Property (Relationships) Act, as amended in 2001, the definitions of "owner" and "property" are unchanged.

30 Matrimonial Property Act 1976, ss 43 and 44. In Coles v Coles (1987) 3 FRNZ 101, 105 (CA) the Court held that the intent required evidence of a conscious desire to remove property from the reach of the Court. While that must have been the aim of the transaction, the Court held in Lowe v Lowe (1987) 3 FRNZ 107 (Family Court) that it did not have to be sole purpose or only reason, but it did have to be the true explanation for the transfer.

31 Working Group Report, above n 23, 28-29. 
devolution of matrimonial property on death and for couples living in de facto relationships, recommended significant changes to the Act. ${ }^{32}$ That was followed by a Law Commission Report in 1997 proposing modernisation of the property sharing regime on death. ${ }^{33}$

By this time it was widely recognised that family property law no longer accurately reflected social reality. ${ }^{34}$ The ongoing failure to extend the equal sharing regime to marriages ending on death was untenable. The rapid rise in the number of de facto relationships and their similarity to marriage made the absence of a statutory sharing regime increasingly difficult to justify. Furthermore, the Act did not produce an equal outcome for the parties. It divided the couple's capital assets, but not their earning capacity. The spouse with primary or ongoing responsibility for the children of the marriage, usually the wife, was often left with a much reduced earning capacity as compared to the earning spouse, usually the husband. ${ }^{35}$ Her limited entitlement to spousal maintenance did not compensate for her loss or her husband's enhanced earning capacity resulting from the division of functions within the marriage. ${ }^{36}$ Clearly it was time for reform.

The first reform proposals were introduced into Parliament in 1998 ${ }^{37}$, but it was not until 2001 that legislation was finally enacted. The Property (Relationships) Amendment Act 2001 implemented many of the recommendations that the Government Working Group had made 13 years earlier. The 2001 Act amended the Matrimonial Property Act 1976 and renamed it the Property (Relationships) Act 1976, because de facto relationships were brought within its ambit. The Amendment Act also added a new part dealing with relationships ending on death and made several other changes to strengthen the equal sharing regime. The changes were hailed as a major advance for the principles of equality and partnership, but they fail to deliver on that promise in several respects.

32 Working Group report, above n 23, 1-2.

33 NZLC Report 39 Succession Law: A Succession (Adjustment) Act (Wellington, 1997).

34 See the opening speech of the Hon Douglas Graham, Minister of Justice, and the papers presented at the Symposium on "Family Property, Law and Policy", held in Wellington in 1994: Bill Atkin, Graeme Austin and Virginia Grainer (eds) Family Property, Law and Policy (New Zealand Institute of Advanced Legal Studies and Victoria University of Wellington Law Review, Wellington, 1995) 4. See also NZLC Preliminary Paper 24 Succession Law: Testamentary Claims and NZLCR 39, above n 33.

35 Hon Douglas Graham, above n 34, 4-5; Regina Graycar "Matrimonial Property Law Reform and Equality for Women: Discourses in Discord" Bill Atkin, Graeme Austin and Virginia Grainer (eds) Family Property, Law and Policy (New Zealand Institute of Advanced Legal Studies and Victoria University of Wellington Law Review, Wellington, 1995) 9-30.

36 Family Proceedings Act 1980, Part 6.

37 The Matrimonial Property Amendment Bill 1998 covered marriages ending on death and the De Facto Relationships (Property) Bill 1998 gave heterosexual de facto couples very similar property rights as married couples, but in a separate statute. 
The remainder of this paper will review the reforms made in 2001 in an attempt to determine whether they represent a conceptual change to New Zealand's relationship property regime.

\section{MODERNISING THE CONCEPT OF PARTNERSHIP}

The Matrimonial Property Act was founded on the concept of partnership, a partnership of equals. That concept determined the classification of the parties' assets and their division at the end of the partnership. But it applied only to marriage. Prior to 2001, de facto relationships were not legally viewed as a partnership of equals. The amended Act does treat a de facto relationship as a partnership, both heterosexual and same sex de facto relationships. ${ }^{38}$ De facto partners enjoy the same relationship property rights as spouses provided they have lived together as a couple for three or more years. ${ }^{39}$ In contrast to a marriage of short duration, the Court generally has no jurisdiction to make orders in respect of a de facto relationship of short duration. ${ }^{40}$ Until a de facto couple has lived together for three years, their relationship does not qualify as a partnership for purposes of this Act. The Act was amended again in 2005 to bring civil unions within its ambit. ${ }^{41}$ Civil union partners are accorded the same rights as spouses and are therefore subject to the Act from the moment the civil union is solemnised. The Act continues to draw a distinction between legal unions and de facto unions, according slightly better entitlements to the legal unions. ${ }^{42}$ Status thus continues to enjoy some preference over contract.

The Act's purpose provision was amended to take account of the inclusion of civil unions and de facto relationships. Section $1 \mathrm{M}$ states that the Act's purpose is to recognise the equal contribution of spouses, civil union partners and de facto partners to their partnerships and to provide for a just division of the relationship property between spouses or partners. ${ }^{43}$ All three relationships are thus characterised as partnerships and they enjoy equivalent, but not identical, standing in this Act.

The inclusion of de facto relationships, especially same sex relationships, in an Act designed for marriage was highly controversial. Most submitters on the Bill opposed the change. So did the

38 Property (Relationships) Act 1976, 1M(b).

39 Property (Relationships) Act 1976, 4(5).

40 Property (Relationships) Act 1976, ss $14 \mathrm{~A}$ and 85.

41 Property (Relationships) Amendment Act 2005.

42 In short duration marriages and civil unions, the presumption of equal sharing is the starting point, but it is easier to rebut on separation: ss 14 and 14AA. If a marriage or civil union ends on death, the ordinary strict presumption of equal sharing applies unless that would be unjust: s 85(1) and (2). This recognises that the relationship did not end voluntarily. This view does not apply to short duration de facto relationships ending on death. They are still not covered by the Act, unless there was a child of the relationship or the applicant partner made a substantial contribution to the relationship and, in either case, a serious injustice would occur if no order were made: s 85(3).

43 Property (Relationships) Act 1976. s 1M. 
National Party. They were concerned that it would damage society by devaluing the institution of marriage. ${ }^{44}$ That was also the reason for removing heterosexual de facto relationships from the Matrimonial Property Bill in $1975 .{ }^{45}$ But by the late nineties attitudes had changed and the opponents were defeated on a conscience vote. ${ }^{46}$ De facto relationships had become an undeniable reality. At the 2001 census 336,594 respondents said they were living in a de facto relationship, compared to 87,960 in 1981 when Statistics New Zealand first started collecting data on de facto relationships. ${ }^{47}$ By 2006 the number had increased again to 428,130. That number, which included a small number of civil unions, constituted 31 per cent of the total number of people living in a married or unmarried partnership.

The Courts were more proactive than Parliament. They had long ago recognised the need to respond to society's changing values and wide acceptance of de facto relationships. ${ }^{48}$ They developed existing property concepts, in particular the law of trusts, to resolve property disputes between former de facto partners and give effect to their common intention or reasonable expectations. ${ }^{49}$ The Courts were careful not to equate de facto relationships with marriage, even if the relationship had lasted for many years and been a marriage in all but name. ${ }^{50}$ Unless the parties had an agreement or common intention that the assets would be shared equally at the end of their relationship, the Courts were reluctant to order equal division. Even if the partners had a reasonable expectation of sharing the property in dispute, their entitlement was uncertain and awards were unpredictable. ${ }^{51}$

44 Justice and Electoral Committee Report on the Matrimonial Property Bill and Supplementary Order Paper No 25 (109-3) 5.

45 Matrimonial Property Bill 1975, cl 49.

46 The inclusion of heterosexual couples was put to the vote first and was won by only four votes. The inclusion of same sex couples was won by a larger majority, because many of the parliamentarians who voted against the inclusion of heterosexual couples voted in favour of same sex couples in the interests of consistency.

47 At the 1991 census 161,856 people said they were living in a de facto relationship and in 1996 the number had risen to 247,293 .

48 Gough v Fraser [1977] 1 NZLR 279 (CA) is the first reported Court of Appeal decision to consider a property dispute between former de facto partners.

49 The leading Court of Appeal decisions are Hayward v Giordani [1983] NZLR 140 (CA); Gillies v Keogh [1989] 2 NZLR 327 (CA) and Lankow v Rose [1995] 1 NZLR 277 (CA).

50 For example, $D$ v A (1992) 9 FRNZ 43 (HC); Phillips v Phillips (1993) 10 FRNZ 110 (CA) and McMahon v McMahon [1997] NZFLR 145 (CA).

51 Mark Henaghan and Nicola Peart "Relationship Property Appeals in the New Zealand Court of Appeal 1958-2008: The Elusiveness of Equality". A paper presented at a symposium to celebrate the 50th anniversary of New Zealand's Permanent Court of Appeal (Wellington, 2008). 
Against this background, it is hardly surprising that when a statutory regime for de facto partners was first proposed in 1998 there was widespread support in the community. ${ }^{52}$ The initial proposal gave heterosexual de facto relationships very similar rights to married couples, but in a separate Act. ${ }^{53}$ Same sex relationships were not included. ${ }^{54}$ That was intended to meet the concerns of those who thought that equating the two unions would erode the special status of marriage. But those concerns were rejected when the final proposal came before the House. A Supplementary Order Paper amending the Matrimonial Property Bill 1998 included both same sex and heterosexual couples within the one Act. ${ }^{55}$ The Act was concerned with property division on the breakdown of a relationship, not moral values.

The inclusion of de facto relationships converted the regime from one based on status to one based on contract. What brings parties within the ambit of the Act is not their legal status, but the fact of living together as a couple. As many married couples and civil union partners live together before legalising their union, entry into the regime is now more likely to be a question of fact than of law.

The inclusion of de facto relationships and civil unions reflects a change in society's perception of marriage. The dramatic increase in the number of de facto relationships suggests that the institution of marriage is not important to many people and, since the adoption of the Civil Union Act in 2004, it no longer holds the unique status it once did. ${ }^{56}$ The distinction between marriage and de facto relationships or civil unions is much less relevant today than it was in the past. Human rights legislation dictates that the law not discriminate on the grounds of marital status or sexual orientation. ${ }^{57}$ Parliament has given effect to this obligation by amending over one hundred statutes to include civil unions and de facto relationships wherever marriage is mentioned. ${ }^{58}$ However, it was unable to amend all statutes because of political opposition and problems of a pragmatic

52 See comments of Hon Douglas Graham, the Minister in charge of the De Facto Relationships (Property) Bill, when he introduced the Bill in 1998: (1998) 38 NZPD 7917-18.

53 De Facto Relationships (Property) Bill 1998.

54 Clause 17 of the De Facto Relationships (Property) Bill defined "de facto relationship" in heterosexual terms.

55 Matrimonial Property Amendment Bill and Supplementary Order Paper No 25, 5 and clause 4 inserting new s $2 \mathrm{D}$.

56 The Births, Deaths, and Marriages Registration Act 1995, renamed the Births, Deaths, Marriages and Relationships Registration Act with effect from 24 January 2009, provides for the registration of civil unions in Part 7A.

57 Human Rights Act 1993, s 21(1)(b) and (m).

58 Most of the amendments were made by the Relationships (Statutory References) Act 2005. 
nature. ${ }^{59}$ The result is an untidy patchwork of laws in which legal and de facto unions are equated for some purposes but not others.

The recognition of de facto relationships poses particular difficulties because of their conceptual uncertainty. ${ }^{60}$ It is impossible to define with any degree of precision what a de facto relationship is. Indeed, New Zealand legislation has two definitions. For most purposes it is defined as living together as a couple in the nature of marriage, ${ }^{61}$ but for purposes of the Property (Relationships) Act it simply means living together as a couple. ${ }^{62}$ Both definitions include same sex couples. When the Property (Relationships) Act was going through the legislative process, the reference to marriage was explicitly rejected as inappropriate, because same sex couples could not marry and other couples had chosen not to do so. ${ }^{63}$ It is beyond the scope of this article to discuss the implications of these different definitions. Suffice to say that both are inherently uncertain and difficult to apply in practice.

The Property (Relationships) Act provides a list of factors to guide the Courts in determining the existence of a de facto relationship, such as the nature and extent of a common residence, whether a sexual relationship exists, the degree of financial dependence or interdependence, the ownership, use and acquisition of property, care and support of children, mutual commitment to a shared life, and the public aspects of the relationship. ${ }^{64}$ These factors are of limited assistance, because the relevant section states that none is essential, either on its own or in combination with others. ${ }^{65}$ For

59 For example, the Adoption Act 1955 was not amended because of concern that gay couples could then adopt. The Wills Act 2007 does not treat de facto partners in the same way as spouses or civil union partners for pragmatic reasons. For instance, Wills Act 2007, s 18, provides that the solemnisation of a marriage or civil union automatically revokes a prior will of either of the parties. The commencement of a de facto relationship has no effect on the validity of a prior will. The commencement of a de facto relationship is too uncertain to have such a far-reaching legal consequence. The Justice and Electoral Committee recommended that references to de facto relationships be inserted on a case by case basis: Report of the Justice and Electoral Committee on the Relationships (Statutory References) Bill, 5.

60 That was identified as a problem in 1975 when it was first proposed to include de facto relationships in the Matrimonial Property Bill: A H Angelo and W R Atkin "the Matrimonial Property Bill 1975 - some further thoughts" [1976] NZLJ 424, 427.

61 That was the definition in Social Security Act 1964, s 63 at the time that the Property (Relationships) Amendment Bill was being debated. The definition now includes a reference to civil unions as well and can be found in Interpretation Act 1999, s 29A.

62 Property (Relationships) Act, s 2D.

63 Justice and Electoral Committee Report on the Matrimonial Property Bill and Supplementary Order Paper No 25, 7 .

64 Property (Relationships) Act, s 2D(2).

65 Property (Relationships) Act, s 2D(3). 
example, it has been established that a shared residence is not required, ${ }^{66}$ nor is a sexual relationship. ${ }^{67} \mathrm{~A}$ de facto relationship has even been found where the couple had decided not to move in together to protect the sensitivities of family members. ${ }^{68}$ No two cases are the same. Even broadly similar factual circumstances may produce different outcomes. ${ }^{69}$ Each case turns on its own particular circumstances. However, one factor that is essential is the parties' mutual commitment to a shared life. That factor differentiates a casual relationship from the kind of relationship that Parliament intended to cover. But a mutual commitment is not enough. While it may signal that the parties are "a couple", they will not come within the Act unless they are also "living together". ${ }^{70}$ There must therefore be evidence that the parties' lives are intertwined in a physical sense. The sharing of a common residence is the most common indicator that the couple is living together, but it may also be inferred from other factors, such as the intermingling of finances. ${ }^{71}$

Since the Property (Relationships) Act came into force on 1 February 2002 there have been many cases where the existence, commencement, or ending of a de facto relationship has been contested. Determining these issues affects whether the parties come within the Act, or the duration of their relationship, or the classification of their assets.

The Act also has retrospective effect. ${ }^{72}$ It applies to marriages and de facto relationships that end on or after 1 February 2002. De facto relationships that immediately preceded a marriage or civil union are treated as part of the marriage or civil union. ${ }^{73}$ This means that transactions made during a de facto relationship before the Act came into force may now have different consequences. ${ }^{74}$ Ascertaining whether a de facto relationship existed or when it began is thus pivotal to determining the parties' relationship property rights.

66 Scott v Scragg [2005] NZFLR 577 (Family Court) and on appeal Scragg v Scott (2006) 25 FRNZ 942 (HC); Galvin v Brocklehurst (2006) 26 FRNZ 28 (HC).

67 Horsfield v Giltrap (2001) 20 FRNZ 404 (CA).

68 Allison v Scott (26 November 2007) Family Court Dunedin FAM 2006-045-58 Judge Smith.

69 Compare, for example, Allison v Scott (26 November 2007) Family Court Dunedin FAM 2006-045-58 Judge Smith with $C \vee A$ (2007) 26 FRNZ 389 (Family Court). See further Nicola Peart "De Facto Relationships (or Maybe Not) in New Zealand" [2008] IFL 113.

70 Lawson v Perkins (2007) 26 FRNZ 946 (HC).

71 As in Scott v Scragg [2005] NZFLR 577 (Family Court) and Allison v Scott (26 November 2007) Family Court Dunedin FAM 2006-045-58 Judge Smith.

72 Property (Relationships) Act 1976, ss 4C and 97.

73 Property (Relationships) Act 1976, ss 2B, 2BAA and 2BA. Section 2BAA is not yet in force.

74 For example, in Boyd v Jackson (6 March 2003) Family Court Napier FP041/363/01 Judge Inglis QC a business acquired during the couple's de facto relationship before their 18 year marriage would have been separate property under the Matrimonial Property Act, but was relationship property under the Property (Relationships) Act. Davies v Waugh (21 June 2006) Family Court Christchurch FAM 2004-009-3422 
The ambit of the Act's application has become very uncertain as a result of the inclusion of de facto relationships. This uncertainty is strangely at odds with the inflexibility of a codified community property system. While parties can opt out of the Act if they wish, they are unlikely to do so if they do not know they are subject to the Act. By the time they realise that they are subject to the Act it may be too late, because rights will have been acquired and any agreement that deprives a partner of those rights may be difficult to negotiate and vulnerable to challenge. ${ }^{75}$ Very few de facto relationships commence with any of the formality or publicly stated commitment that is required for a marriage or civil union. So, while many de facto relationships will in substance be partnerships in the sense intended by the Act, determining whether a relationship meets that standard will be a retrospective decision rather than a prospective one. While retrospectivity is not necessarily inconsistent with a deferred property sharing regime, it is inconsistent with the Act's opt out nature.

\section{CHANGES TO THE PROPERTY SHARING REGIME}

The Property (Relationships) Amendment Act 2001 also made many changes to the property sharing regime. Some of these changes strengthen the community property aspects of the regime, while others detract from it.

\section{A Presumption of Equal Sharing Strengthened}

One of the most significant changes is the abolition of the distinction between domestic assets and the balance of relationship property. All relationship property is now equally shared unless the relationship is of short duration or there are extraordinary circumstances that make equal sharing repugnant to justice. ${ }^{76}$ The latter exception was notoriously difficult to satisfy under the old Act, when it applied only to the matrimonial home and family chattels. ${ }^{77}$ That is still the case under the amended Act, even though it now applies to all relationship property and to a wider range of relationships. ${ }^{78}$ The discretion to depart from equal division is extremely limited.

The repeal of the weaker presumption in relation to non-domestic matrimonial property means that equal division of all relationship property is now virtually inevitable. The very narrow exceptions to equal sharing suggest a conceptual shift from a system of deferred participation to a

Judge Chris Somerville where the applicant did not support her partner's decision in 1994 to buy a property and made no contributions to its acquisition or improvement. When they separated in 2003, she was entitled to a half share under the Property (Relationships) Act.

75 Harrison v Harrison [2005] 2 NZLR 349 (CA) para 112.

76 Property (Relationships) Act, s 13 and ss 14 to 14AA.

77 Matrimonial Property Act 1976, s 14.

78 In $P$ v $P$ (2002) 22 FRNZ 380 (Family Court) Judge Inglis QC suggested that there was scope to liberalise the extraordinary circumstances exception, but in De Malmanche $v$ De Malmanche [2002] 2 NZLR 838 (HC) the Court saw no reason to lower the threshold because the wording of the exception had not changed. 
system of deferred community of property. This is especially true for couples who bring no general assets into their relationship. All of their assets, other than assets received gratuitously from a third party, will be equally shared, including any business or farming assets acquired during the relationship. ${ }^{79}$

\section{B Contracting Out of the Act}

Public acceptance of the Act's expanded ambit, and in particular the inclusion of de facto relationships, was based in part on the fact that people could opt out of the statutory regime and make their own arrangements. That was an integral feature of the Act's public legitimacy. ${ }^{80}$ To redress criticism about the ease with which such agreements had been set aside in the past, Parliament changed the threshold for setting aside relationship property agreements from injustice to serious injustice and required the Court to have regard to the fact that the parties wished to achieve certainty by entering into the agreement. ${ }^{81}$ That change is reflected in the case law. ${ }^{82}$ Economic disparity between the contractual entitlement and the statutory entitlement is no longer a sufficient reason for setting aside a contracting out agreement. Nor is the existence of some pressure to enter into the contract. As the Court of Appeal observed in Harrison v Harrison: ${ }^{83}$

In the case of a contracting out agreement... the very purpose of the parties is to make provision which differs from the statutory regime. ...

It will almost always be the more affluent party who wants a contracting out agreement and it will often be the case that the other party only signs the agreement given the implications for the relationship if he or she declines to do so...

We are conscious that the latter way of looking at the situation might be thought to be a little bleak and emotionless. It is, however, consistent with the legislative scheme.

79 Assets received from a third person by way of gift, inheritance, survivorship, or as a beneficiary of a trust settled by a third person are separate property of the recipient, because they are not produced by the partnership: Property (Relationships) Act 1976, s 10. See for example Nation v Nation [2005] 3 NZLR 46 (CA) where the half share of the farm that the husband purchased from his family during the marriage was relationship property and subject to equal division. The other half share was acquired as a beneficiary of a family trust and was his separate property.

80 Wells $v$ Wells [2006] NZFLR 870 (HC) para 38.

81 Property (Relationships) Act 1976, s 21J.

82 The leading case is the Court of Appeal decision in Harrison v Harrison [2005] 2 NZLR 349 (CA). See also $C$ v S [2004] NZFLR 546 (HC); Wells $v$ Wells [2006] NZFLR 870 (HC). In $F v H$ [2008] NZFLR 425 (Family Court) the Court even declined to set aside an agreement that classified the family home as the husband's separate property. Although that was the couple's major asset, it was a marriage of short duration and the agreement was not unfair at the time it was made, nor had it become unfair.

83 Harrison v Harrison [2005] 2 NZLR 349 (CA) paras 81, 90 and 91. 
The context and history of the Property (Relationships) Amendment Act 2001 meant that, at least for contracting out agreements, "serious injustice" required evidence of an unsatisfactory process resulting in inequality of outcome rather than mere inequality of outcome itself. Settlement agreements might be different, because they are made "in respect of entitlements already accrued and should reflect the reality of those entitlements". ${ }^{84}$

The strengthening of the opt out system brings the Property (Relationships) Act into line with community property systems found in civil law jurisdictions where there are generally no special provisions for setting aside agreements if they were made in accordance with the prescribed requirements. ${ }^{85}$

\section{Compensation for Dispositions of Relationship Property to Trusts and Companies}

The Act provides only one legitimate avenue for avoiding the equal sharing regime and that is by contracting out of the Act in accordance with the prescribed requirements. The reality is rather different. Trusts and companies are a common way of avoiding the relationship property regime. Substantial amounts of relationship property are being disposed of to trusts or companies, frequently to the detriment of one of the spouses or partners. The Government Working Group identified this as a problem in 1988, observing that "unless matrimonial property remains such during the marriage, becoming available for equal division in due course, the social purpose of a joint matrimonial property law is lost". ${ }^{86}$

Sections 44C and 44F were inserted into the Act in 2001 to deal with this problem. They are based on the 1988 Working Group's recommendations. They provide that, if a disposition of relationship property to a trust or company has the effect of defeating the rights of one of the spouses or partners, the other spouse or partner may be ordered to compensate the disadvantaged spouse or partner. The aim of these provisions is to redress the unequal benefits resulting from dispositions of relationship property. ${ }^{87}$ Although compensation is at the discretion of the Court, it must be exercised to give effect to the Act's purpose of achieving a just division of relationship property between the spouses or partners, which generally means equal division. The discretion relates to the means by which that purpose is to be achieved, not to whether equal division is just in

84 Harrison v Harrison [2005] 2 NZLR 349 (CA) para 112.

85 For example, Title 8 in Book 1 Burgerlijk Wetboek (Netherlands) stipulates that a marriage contract must be made by notarial instrument and be registered in the Matrimonial Property Register. But there is no provision for the Court to set aside a contract that complies with those requirements.

86 Working Group Report, above n 23, 30. See also Maureen Southwick "Family Trusts - Time for Reconsideration?" in Bill Atkin, Graeme Austin and Virginia Grainer (eds) Family Property, Law and Policy (New Zealand Institute of Advanced Legal Studies and Victoria University of Wellington Law Review, Wellington, 1995) 87.

87 Nation v Nation [2005] 3 NZLR 46 (CA). 
the circumstances. Orders under these provisions have reflected this aim. ${ }^{88}$ Sections $44 \mathrm{C}$ and $44 \mathrm{~F}$ can thus be seen as enhancing the community property concept.

However, the effectiveness of these provisions is severely curtailed by the sources from which compensation may be ordered. For dispositions to companies, compensation may only be ordered from the respondent's separate property or share of the relationship property. ${ }^{89}$ If there is no such property, the Court has no power to make orders against either the income or the capital of the company. The Court is somewhat less constrained if the dispositions were made to a trust. If there is insufficient separate property or relationship property from which to order compensation, the Court may order the trustees to divert income from the trust to the applicant spouse or partner. ${ }^{90}$ The Court has no power under s $44 \mathrm{C}$ to award compensation from the trust capital.

The 1988 Government Working Group predicted that there would be situations where the Court would need to have access to the capital in order to achieve a just division under the Act and recommended that it be given a wide discretion to order distribution of capital. ${ }^{91}$ But that recommendation was not adopted. The Court now frequently resorts to other remedies, such as section 182 of the Family Proceedings Act 1980, to gain access to trust capital in an attempt to give effect to the aims of the relationship property regime. ${ }^{92}$ It does so despite the fact that the Property (Relationships) Act is a code. ${ }^{93}$ But it cannot do so in all circumstances. For example, de facto partners cannot invoke section 182 Family Proceedings Act. It is only available to spouses and civil union partners, and only at the time of their divorce. Trusts and companies thus continue to undermine the relationship property regime and to the extent that compensation cannot be achieved they fail to give proper effect to the community property regime.

\section{Compensation for Economic Disparity}

While the forgoing changes have generally enhanced the community property regime, the new economic disparity provisions in sections 15 and 15A are fundamentally at odds with that regime. They empower the Court to compensate a spouse or partner whose future income and living standards are significantly lower than the other spouse or partner because of the effect of the

88 For example $S$ v M (16 November 2006) Family Court Tauranga FAM 2004-070-823 Judge Annis Somerville; Hodgkinson v Hodgkinson [2003] NZFLR 780 (Family Court); Stewart v Stewart [2003] NZFLR 400 (Family Court); AJR v RWR (31 October 2008) Family Court Hamilton FAM 2004-019001345 Judge Riddell.

89 Property (Relationships) Act 1976, s 44F(2).

90 Property (Relationships) Act 1976, ss 44C(2)(c) and (3)(a).

91 Working Group Report, above n 23, 30.

92 For example, Fielding v Burrell [2005] NZFLR 558 (HC); Cooper v Cooper (13 July 07) High Court Nelson CIV 2007-442-241 Wild J.

93 Property (Relationships) Act 1976, s 4. 
division of functions during the relationship. These provisions were inserted because the Matrimonial Property Act did not adequately recognise the full effects of the partnership. It divided the gains and losses made in terms of capital, but did not divide the gains and losses made in terms of earning capacity.

In $Z \vee Z$ (No 2) counsel for the wife argued that the husband's future earning capacity should be classified as relationship property and thus be divisible under the Act, but the Court of Appeal rejected that argument. ${ }^{94}$ Sections 15 and $15 \mathrm{~A}$ do not treat future earning capacity as property either, nor do they purport to achieve equality, assuming that were a possibility. Instead, the Court is given a wide discretion to order compensation from the higher earner's share of the relationship property. An order under these provisions therefore results in a discretionary readjustment of the division of relationship property, which is inconsistent with a community property regime. ${ }^{95}$ As Atkin recently observed, "this new discretionary power cuts across the concept of a rule-based regime of property division".96

When the Bill was debated by the Committee of the Whole House, the then Associate Minister of Justice said that section 15 would apply to "the exceptional case, not the norm".97 That has not been the case. Section 15 is commonly invoked, though with mixed success. Applicants often do not meet the jurisdictional requirements and when they do the awards have generally been modest. That does not detract from the fact that the provision does not fit conceptually with the Act's property sharing regime and even less so with the shift towards a stronger community property regime. There is no formula to assess quantum and, as one Court of Appeal judge observed, awards are "necessarily a matter of impression". ${ }^{98}$ Such unpredictability has no place in a code of rules that is expected to provide an inexpensive, speedy, and simple resolution to relationship property questions. ${ }^{99}$ It thus flouts one of the four principles of the Act. ${ }^{100}$

94 [1997] 2 NZLR 258 (CA).

$95 \quad M v B$ [2006] 3 NZLR 660 (CA) para 123.

96 Bill Atkin "The Legal World of Unmarried Couples - Does the New Zealand Approach Shed any Light on the Future?" $13^{\text {th }}$ World Conference of the International Society of Family Law, Vienna 2008, published in (2008) 39 VUWLR 793.

97 (1998) 591 NZPD 8625.

98 In $M v B$ [2006] 3 NZLR 660 (CA) para 147 per Robertson J.

99 Section $1 \mathrm{~N}(\mathrm{~d})$.

100 See further Bill Atkin "Economic disparity - how did we end up with it? Has it been worth it?" (2007) 5 NZFLJ 299; Joanna Miles "Financial Provision and Property Division on Relationship Breakdown: A Theoretical Analysis of the New Zealand Legislation" (2004) 21 NZULR 268 and "Dealing with Economic Disparity: An Analysis of Section 15 Property (Relationships) Act 1976" [2003] NZ Law Rev 535. 


\section{E Death}

The new provisions inserted in Part 8 to govern relationship property rights on death are also conceptually at odds with the rest of the Act's regime. When the relationship ends on death there is no automatic division of relationship property, as there would be in civil law jurisdictions. ${ }^{101}$ Instead, the surviving spouse or partner has to elect to apply for a division. ${ }^{102}$ If he or she does not do so within the prescribed time and in the prescribed manner, ${ }^{103}$ the estate is distributed in accordance with the will or the intestacy provisions, ${ }^{104}$ subject to any adjustments under the Family Protection Act 1955 and the Law Reform (Testamentary Promises) Act 1949. If division is sought, the survivor loses his or her succession entitlement unless a contrary intention is expressed in the deceased's will or the Court reinstates some or all of the forfeited inheritance. ${ }^{105}$

By forcing the survivor to make a choice between his or her relationship property entitlement and inheriting from the deceased, the Act merges two distinct concepts. When a widow chooses to apply for a division, she is claiming what is rightfully her property. When she inherits she receives what is her husband's property. The former is the payment of a debt, while the latter is a duty to support and provide for the wife. The election merges the debt and the duty.

The second conceptually inconsistent feature about the death provisions is that the personal representative of the deceased cannot apply for a division of relationship as of right. He or she may do so only with leave from the Court, which may not be granted unless serious injustice would otherwise result. ${ }^{106}$ As originally drafted, there was no provision for an application by the estate. That accorded with the recommendation of the 1988 Government Working Group, which was unanimous in its view that the estate should not be entitled to sue the survivor: ${ }^{107}$

Where one spouse has died the contest is no longer between two partners who take their share and then go their different ways. It is between the survivor of a marriage and the beneficiaries under a will or on an intestacy, or potential family protection claimants.

While the deceased partner has no personal need for his or her share of the relationship property, the Working Group's reason for denying the estate the right to seek a division ignores the possibility that others may be dependent on the deceased or have a moral or legal claim against the estate

101 For example, art 99 Book 1 Burgerlijk Wetboek (Netherlands) and §1476 and §1482 BGB (Germany).

102 Property (Relationships) Act 1976, s 61.

103 Property (Relationships) Act 1976, ss 62 and 65.

104 Property (Relationships) Act 1976, s 68.

105 Property (Relationships) Act 1976, ss 75-77.

106 Property (Relationships) Act 1976, s 88(2).

107 Working Group Report, above n 23, 46. 
which would be frustrated if the estate were unable to compel a division of the couple's relationship property. In response to submissions, the Bill was amended to provide for an application by the estate, but only with leave from the Court.

The serious injustice threshold was at first thought to set a high standard, so that the granting of leave would be the exception rather than the rule. ${ }^{108}$ But the Court of Appeal clarified that leave should be granted whenever a meritorious claim would otherwise be precluded. ${ }^{109}$ On that construction of the serious injustice requirement the obstacle to the estate obtaining a division has all but been removed. Nonetheless, by favouring the surviving spouse or partner over the estate of the deceased spouse or partner, the notion of a partnership of equals is lost and the community is disregarded. Duty then trumps the debt. The community property regime that dominates the inter vivos provisions has therefore not been fully extended to relationships ending on death.

\section{CONCLUSION}

The Property (Relationships) Amendment Act 2001 has changed the conceptual basis of the relationship property regime, but not in a coherent or principled manner. Some of the changes have strengthened the community property concept, in particular the abolition of the distinction between domestic and non-domestic relationship property for purposes of the division of relationship property. The economic disparity provisions, on the other hand, undercut the community property concept by introducing a strong element of discretion, and the death provisions confuse the concept of duty with the concept of entitlement or debt. The opt out nature of the regime has been strengthened, but access to the regime is unclear because of the inherent uncertainty as to the meaning of a de facto relationship.

Whereas the Matrimonial Property Act was a predictable and simple system of deferred participation in a community of assets that operated increasingly as a deferred community property system, the Property (Relationships) Act detracts from that predictability and simplicity. The hope that Angelo and Atkin had for the Matrimonial Property Act, and that was largely realised, has been dashed by the Property (Relationships) Amendment Act. The Act does not steer "an acceptable middle course" between competing demands. It has lost its way.

108 Re Williams [2004] 2 NZLR 132 (HC).

109 Public Trust $v$ Whyman [2005] 2 NZLR 696 (CA). 